\title{
Purification and thrombolytic effects in vivo of recombination Nattokinase on carrageenan-induced tail thrombosis in a rat model
}

\author{
Tran Quoc Tuan ${ }^{*}$, Dinh Thi Lan Anh ${ }^{1}$, Le Thi Thuy Ai ${ }^{2}$, Dinh Minh Hiep ${ }^{2}$, Tran Cat Dong ${ }^{3}$ \\ ${ }^{1}$ University of Sciences, Viet Nam National University Ho Chi Minh City, Vietnam \\ ${ }^{2}$ Agricultural Hi-Tech Park of Ho Chi Minh City, Vietnam \\ ${ }^{3}$ University of Medicine \& Pharmacy at Ho Chi Minh City, Vietnam \\ *Corresponding author: trqtuan@ hcums.edu.vn
}

\begin{abstract}
ARTICLE INFO
ABSTRACT

DOI: $10.46223 / \mathrm{HCMCOUJS.}$ tech.en.8.1.907.2018

Received: February $06^{\text {th }}, 2018$

Revised: March 20 $0^{\text {th }}, 2018$

Accepted: April 16 $6^{\text {th }}, 2018$

\section{Keywords:}

bacillus subtilis, carrageenan, purification, recombinant nattokinase, thrombosis

Nattokinase is a serine protease with fibrinolytic activity and has been proven clinical efficacy and safe for human use by the oral route. In this study, conducted purified recombinant nattokinase from Bacillus subtillis DB104 strain and thrombolytic effects of nattokinase have been observed in vivo. The result of the enzyme purification by membrane filtration method for enzyme recovery efficiency is $82.45 \%$. Then the enzyme was purified to Q-Sepharose ion-exchange chromatography with a purification factor of 1.82 and at a yield of $66.91 \%$. Enzyme activity was 5,457 FU/mg protein. With the carrageenan-induced tail thrombosis in a rat model, results were significantly reduced by 67.3 to $83.6 \%$ at oral doses and injected nattokinase compared with the control group at $48 \mathrm{~h}$. At 72 hours the rate increased to $82-$ $89 \%$ in the oral dose and up to $91 \%$ in the injected dose nattokinase and comparable to $90 \%$ for heparin-positive hepatitis.
\end{abstract}

\section{Introduction}

Thrombosis is a leading cause of morbidity and mortality throughout the world. Hence, the search for a fibrinolytic agent to treat thrombosis continues. Nattokinase, a potent fibrinolytic enzyme, was primarily isolated from a traditional Japanese fermented food 'Natto' by Sumi, Hamada, Nakanishi, and Hiratani (1990). It has 4 times greater fibrinolytic activity than plasmin (Sumi et al., 1990). The enzyme was reported not only to possess tissue plasminogen activator activity (Kotb, 2012) but also to directly digest fibrin by limited proteolysis (Fujita et al., 1995). Nattokinase has been shown to potentiate fibrinolysis by cleaving the t-PA inhibitor type I into low molecular weight fragments, leading to efficient lysis of blood clots in the body (Urano, Ihara, \& Umemura, 2001).

In the process of nattokinase purification, the traditional protein separation and purification techniques, such as organic solvent fractionation, salting out and protein chromatography, have been tested with a number of disadvantages, such as long separation and purification time required, more operation units and less activity recovery (Nakanishi, Nomura, 
Tajima, \& Hiratani, 1998; Urano et al., 2001). Nakanishi produced nattokinase by a procedure consisting of alcohol or ammonium sulfate precipitation, hydrophobic interaction chromatography, ion-exchange chromatography and gel filtration (Nakanishi et al., 1998).

In the present study, we report on the purification and characterization of recombinant nattokinase produced from Bacillus subtilis DB104 (Tran, Le, Dinh, \& Tran, 2013). The fibrinolytic enzyme was purified to electrophoretic homogeneity and its biochemical and thrombolytic activity were investigated. Carrageenan was intravenously administered to the tails of rats at 30 minutes after gavage administration of nattokinase, thereby inducing thrombus formation, and the length of the infarcted region was measured. The efficacy of carrageenan in inducing thrombus formation was evaluated by comparing the lengths of infarcted regions in the tails of rats in the nattokinase administered group with those in the tails of control rats. The action of nattokinase against thrombosis was evaluated by performing these experiments.

\section{Materials and methods}

\subsection{Materials}

\subsubsection{Microorganism and its maintenance}

B. subtilis pBG01-aprN/BD104, containing the gene coding for nattokinase under the control of the inducible promoter $\mathrm{P}_{\text {Sgrac }}$ was preserved in our laboratory (Tran et al., 2013). Bacteria were maintained as spores suspended in $50 \%(\mathrm{v} / \mathrm{v})$ glycerol, stored at $-25^{\circ} \mathrm{C}$. Bacteria were cultured at $37^{\circ} \mathrm{C}$ in Luria-Bertani (LB) medium for culture collection and in fermentation medium (yeast extract $10 \mathrm{~g} \mathrm{l}^{-1}, \mathrm{CaCl}_{2} 5 \mathrm{~g} \mathrm{l}^{-1}$, glucose $2 \mathrm{~g} \mathrm{l}^{-1}$ and $\mathrm{NaCl} 10 \mathrm{~g} \mathrm{l}^{-1}$ ) for enzyme purification. Chloramphenicol $\left(10 \mu \mathrm{g} \mathrm{ml}^{-1}\right)$ was added to the growth medium when necessary.

\subsubsection{Animals}

The healthy male and female Swiss rats weighing 18-22 g approximately 4-6 weeks old were provided by the Ho Chi Minh City Pasteur Institute. The animals were maintained in humidity-controlled rooms with a 12-hour light/dark cycle (light period 7:00 am to 7:00 pm) at $22 \pm 3{ }^{\circ} \mathrm{C}$. All the animals were maintained on tap water and a normal pellet diet for at least 3 days before the following experiments were performed.

\subsubsection{Chemicals and reagents}

Fibrinogen, thrombin, k-carrageenan were purchased from Sigma Aldrich (USA). QSepharose and Sephadex - G75 were purchased from GE Healthcare Life Sciences, Ltd. (Uppsala, Sweden). All other reagents were of the highest quality commercially available.

\subsection{Analytical methods}

2.2.1. SDS-PAGE and fibrin zymography Protein concentration was determined by

Bradford (1976) method using bovine serum albumin (BSA) as the standard protein. Sodium dodecyl sulfate-polyacrylamide gel electrophoresis (SDS-PAGE, 12.5\%) was performed to determine the molecular mass of the enzyme's purity following the methods of Laemmli (1970). 
Nattokinase activities were assessed using fibrin zymography as previously described methods Kim, Choi, and Lee (1998). Briefly, resolving gel solution (12\%) was prepared with $0.12 \%(\mathrm{w} / \mathrm{v})$ fibrinogen and thrombin $(1 \mathrm{U} / \mathrm{ml})$. After PAGE, the gel was treated with $2.5 \%$ Triton X-100, $5 \mathrm{mM} \mathrm{CaCl}_{2}, 50 \mathrm{mM}$ Tris- $\mathrm{HCl}(\mathrm{pH}$ 7.5) for removing SDS and incubated 3 times in the same buffer for $15 \mathrm{~min}$ each, followed by incubation overnight $(16 \mathrm{~h})$ at $37{ }^{\circ} \mathrm{C}$ in $5 \mathrm{mM}$ $\mathrm{CaCl}_{2}, 50 \mathrm{mM}$ Tris- $\mathrm{HCl}$ ( $\mathrm{pH} 7.5$ ). The gel was stained with Coomassie Brilliant Blue $\mathrm{G}(0.5 \%$, $\mathrm{w} / \mathrm{v}$ ) and destained with methanol/acetic acid/water (45:10:45). The area of fibrin degradation on the gel zymography was depicted as clear bands against a blue background of undegraded fibrin.

\subsubsection{Determination of the fibrinolytic nattokinase activity}

Nattokinase activity was measured using a fibrin degradation assay developed by Japan Bio Science Laboratory Co., Ltd. (JBSL) (Japan Nattokinase Association, 2000). To $1.4 \mathrm{~mL}$ of $50 \mathrm{mM}$ sodium borate buffer (pH8.5), a $0.4 \mathrm{~mL}$ of $0.72 \%(\mathrm{w} / \mathrm{v})$ fibrinogen solution was added and kept at $37^{\circ} \mathrm{C}$ for $5 \mathrm{~min}$. To the resulting, fibrinogen solution was then added $0.1 \mathrm{~mL}$ of thrombin $(20 \mathrm{U} / \mathrm{mL})$ and kept at $37^{\circ} \mathrm{C}$ for another $10 \mathrm{~min}$. After the addition of $0.1 \mathrm{~mL}$ of the enzyme, the proteolytic reaction was performed at $37^{\circ} \mathrm{C}$ for $60 \mathrm{~min}$. After the reaction was ceased by adding $2 \mathrm{~mL}$ of $0.2 \mathrm{M}$ trichloroacetic acid (TCA), samples were kept at ambient temperature for $20 \mathrm{~min}$ and then centrifuged at $14000 \mathrm{rpm}$ for $5 \mathrm{~min}$. In this assay, 1 unit (fibrin degradation unit, FU) of enzyme activity is defined as a 0.01 -per-minute increase in absorbance at $275 \mathrm{~nm}$ of the reaction solution.

\subsubsection{Purification of nattokinase}

All steps in the purification procedure were operated at room temperature except for centrifugation, which was conducted at $4{ }^{\circ} \mathrm{C}$. The supernatant of the crude enzyme was obtained by centrifugation at $7000 \mathrm{rpm}$ for $30 \mathrm{~min}$, and then the precipitate was precipitated by the addition of solid ammonium sulfate at $40 \%-70 \%$ saturation. The precipitate was allowed to form at $4{ }^{\circ} \mathrm{C}$ overnight and was collected by centrifugation at $10,000 \mathrm{rpm}$ for $20 \mathrm{~min}$ at $4^{\circ} \mathrm{C}$ for further purification. The precipitate was dissolved in $20 \mathrm{mM}$ Tris- $\mathrm{HCl}(\mathrm{pH} \mathrm{9.4)} \mathrm{buffer.} \mathrm{The}$ solution was dialyzed against the same buffer overnight. Enzyme activity and protein content were determined in the fraction.

The concentrated crude enzyme solution was loaded onto a Q-Sepharose column $(1.6 \times$ $15 \mathrm{~cm}$, bed volume $25 \mathrm{~mL}$ ) (AKTA system) which was preequilibrated with buffer. The column was washed with 6-bed volumes of $10 \mathrm{mM}$ Tris buffer ( $\mathrm{pH} 9.4)$ to remove all unbound proteins and eluted with a linear gradient of 0 to $1 \mathrm{M} \mathrm{NaCl}$ in the same buffer at a flow rate of $1 \mathrm{~mL} / \mathrm{min}$. The fractions with fibrinolytic activity were pooled, concentrated with ammonium sulfate. The precipitate was collected by centrifugation at $10,000 \mathrm{rpm}$ for $20 \mathrm{~min}$ at $4{ }^{\circ} \mathrm{C}$, dissolved in $10 \mathrm{mM}$ Tris buffer ( $\mathrm{pH} 7.8$ ), and dialyzed against the same buffer overnight. The sample was loaded onto a Sephadex G-75 gel filtration column $(2.6 \times 90 \mathrm{~cm})$ (AKTA system) which was preequilibrated with $10 \mathrm{mM}$ Tris buffer $(\mathrm{pH}$ 7.8). The column was eluted with the same buffer at a flow rate of $0.4 \mathrm{~mL} / \mathrm{min}$.

Elution peaks were collected, and the enzyme activity and protein concentration in each fraction were determined, respectively. The fraction containing the enzyme with the highest 
activity was collected and concentrated by ultrafiltration. The active fraction was pooled, concentrated, analyzed for purity by SDS-PAGE, then dried by freeze-dryer.

\subsubsection{Rat model of carrageenan-induced thrombosis}

Rats with tails longer than $9 \mathrm{~cm}$ were selected and anesthetized using diethyl ether for the experiments. To assess the in vivo thrombolytic activity, a total of 30 rats were randomly subdivided into 5 groups, each group containing 6 rats. Group 1 rats were injected with $10 \mathrm{mM}$ Tris buffer ( $\mathrm{pH} 7.8$ ), which served as the control (placebo). The animals in groups 2 and 3 were treated with graded concentrations ( 200 and $400 \mathrm{ul}$ nattokinase, respectively). The rats in groups 4 and 5 were injected into the tail vein from the tip of the rat tail with a 50ul dose of nattokinase and $50 \mathrm{ul}$ of $100 \mathrm{IU}$ heparin sodium, respectively. After 30 minutes of intravenous doses of nattokinase, the tails were ligated and $1 \mathrm{mg} / \mathrm{kg}$ body weight of $\mathrm{k}$-carrageenan was induced through intravenous injection. The ligatures were removed after 15 minutes of injection. The length of the infarcted region was measured, and the appearance of the wine-colored thrombus formation in the tails was photographed after 24,48 and 72 hours of treatment by the abovementioned thrombolytic agents.

\section{Results and discussion}

\subsection{Purification of nattokinase}

Nattokinase produced by B.subtilis DB104 was purified by a simple method consisting of precipitation (Table 1). Most of the enzyme activity was achieved at $40-70 \%$ saturation ammonium sulfate fraction having $298,500 \mathrm{FU}$, in which specific activity was $3,142 \mathrm{FU} / \mathrm{mg}$ protein with a yield of $75.65 \%$ (Table 1). It is noted that ammonium sulfate salts are the most widely used in the concentration of enzymes due to high solubility and low cost, compared with the other organic solvents and no effect on $\mathrm{pH}$ or the stability of the enzyme (Whitaker, 1972).

In other studies, the activity of precipitates in the crude enzyme supernatants with 30$80 \%$ saturations $\left(\mathrm{NH}_{4}\right)_{2} \mathrm{SO}_{4}$ was contrasted. To preserve the fibrinolytic activity of fibrinolytic enzyme as much as possible, according to the activity assay, the precipitate formed in 30-60\% saturation of $\left(\mathrm{NH}_{4}\right)_{2} \mathrm{SO}_{4}$ was collected (Wang et al., 2009). The fibrinolytic enzyme was also purified by ammonium sulfate saturation. The protein fraction was precipitated with $85 \%$ ammonium sulfate (Dubey, Kumar, Agrawala, Char, \& Pusp, 2011).

In the present study, the activity of the precipitates in the crude enzyme supernates with $30-90 \%$ saturations $\left(\mathrm{NH}_{4}\right)_{2} \mathrm{SO}_{4}$ was contrasted. To preserve the fibrinolytic activity of nattokinase as much as possible, according to the activity assay, the precipitate formed in 50$70 \%$ saturation of $\left(\mathrm{NH}_{4}\right)_{2} \mathrm{SO}_{4}$ was collected. Then the dialyzed precipitate was applied to Qsepharose. 


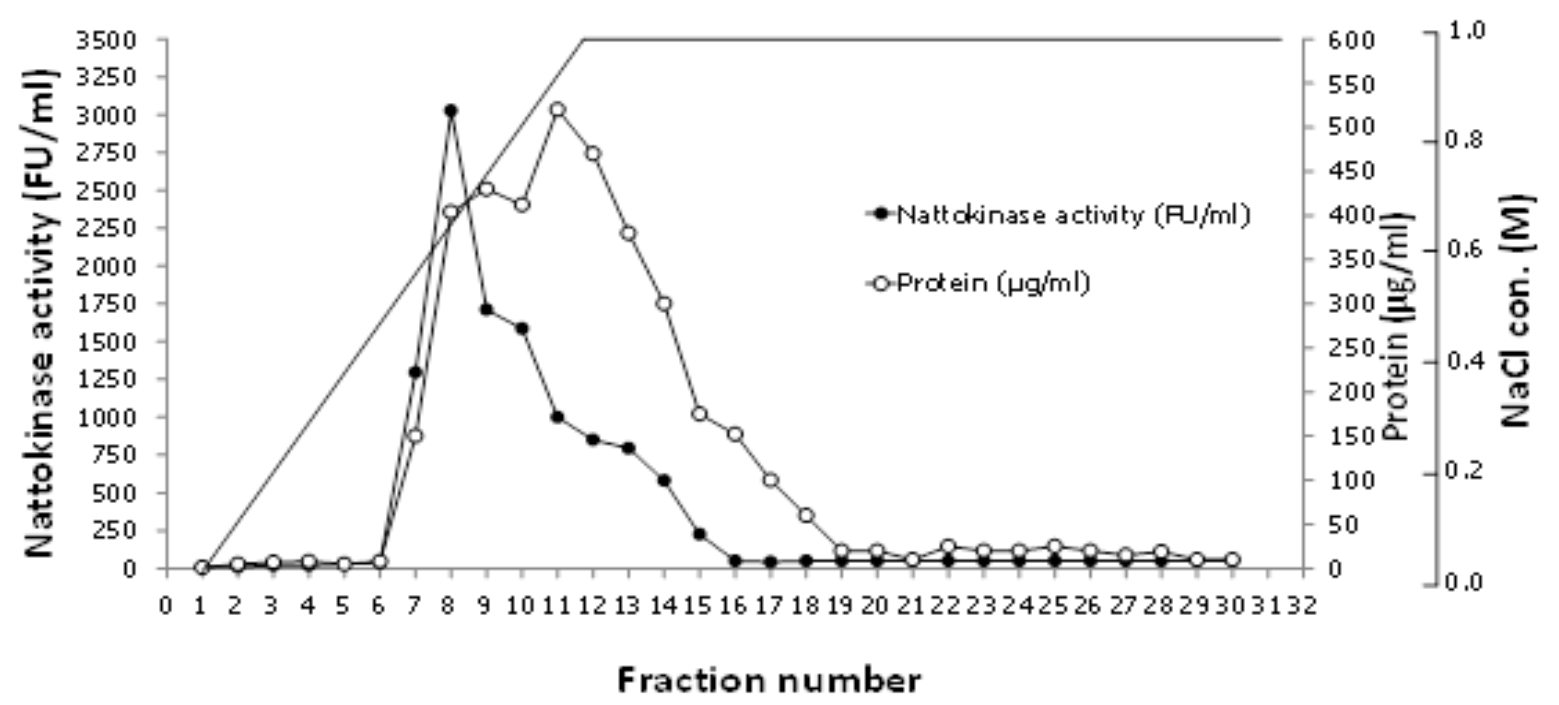

Figure 1. Q-sepharose ion exchange chromatography for purified nattokinase from B. subtilis DB104 by using Q-sepharose column. Nattokinase activity (FU/ml) (O), Protein

$(\mu \mathrm{g} / \mathrm{ml})(\mathrm{O})$

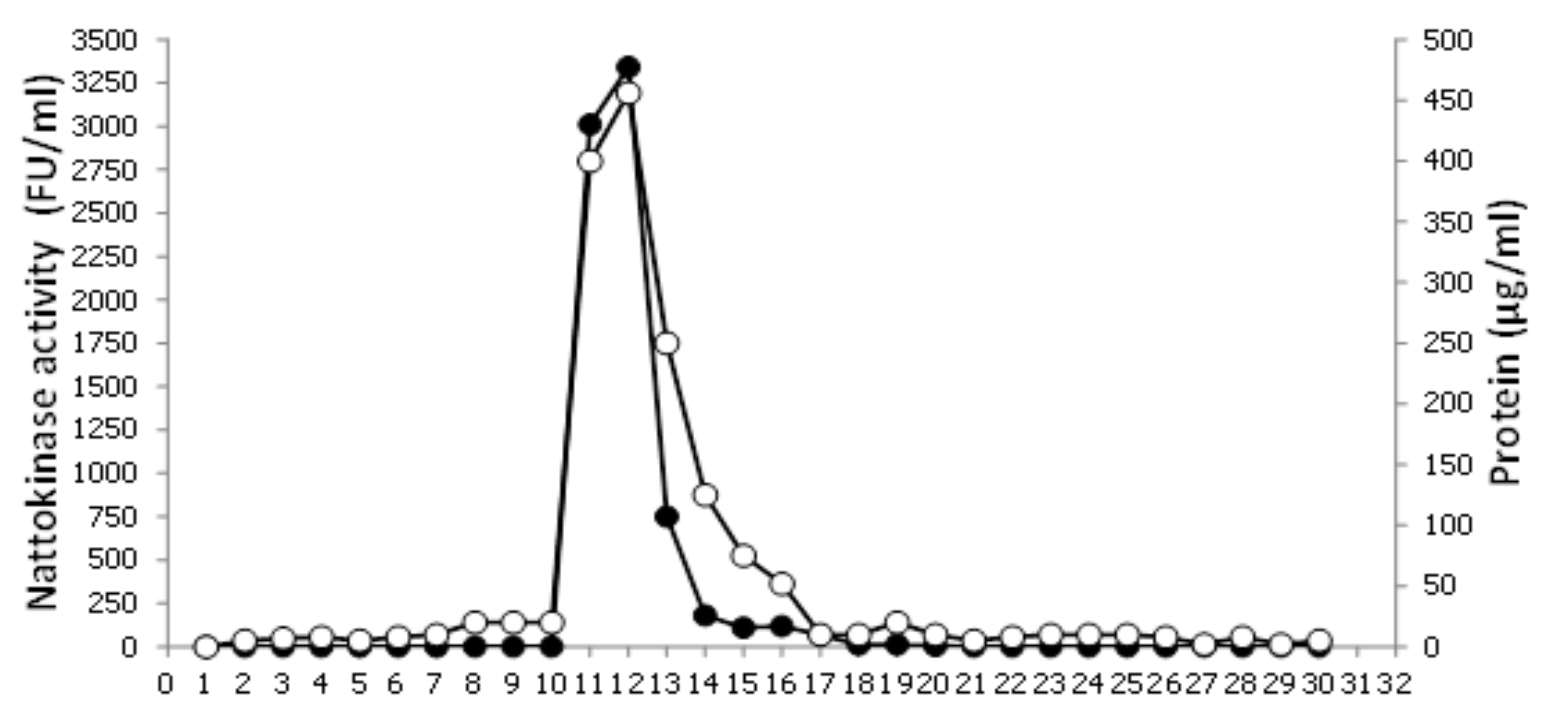

Fraction number

Figure 2. Gel filtration chromatography for purified nattokinase from B. subtilis DB104 by using Sephadex G75 column. Nattokinase activity (FU/ml) ( $)$, Protein $(\mu \mathrm{g} / \mathrm{ml})$ (O) 


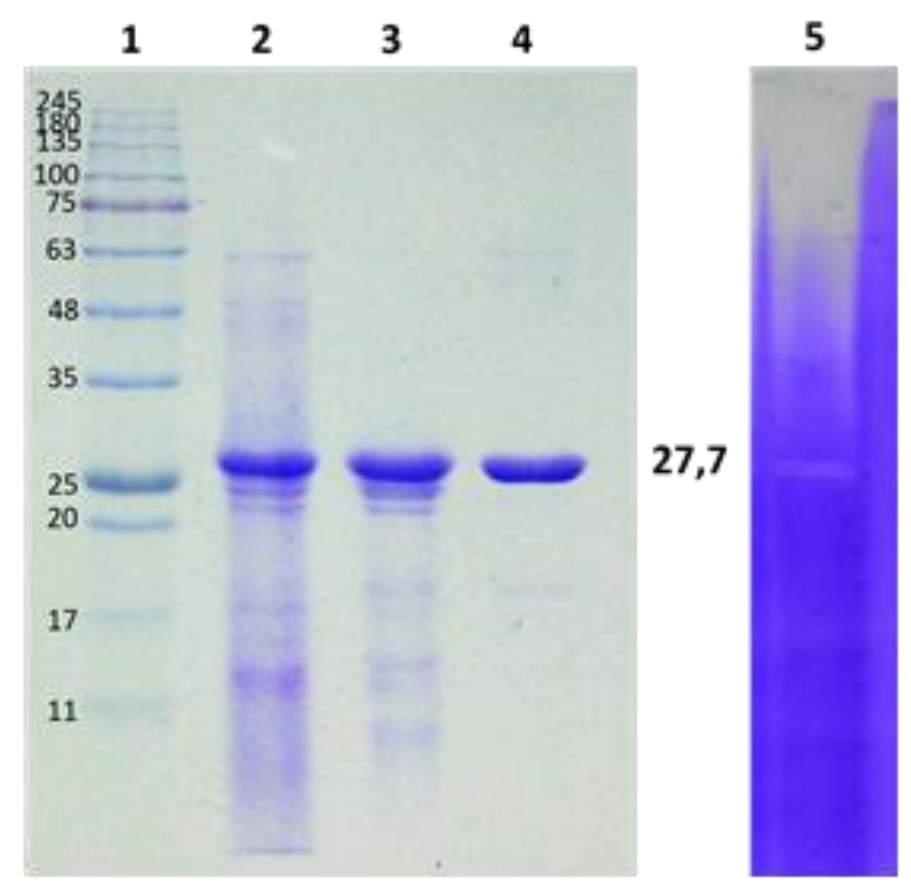

Figure 3. SDS-PAGE analysis of the purified nattokinase expressed in B. subtilis DB104. Lane 1, protein molecular weight marker; lane 2, concentrated enzyme from ammonium sulphate precipitation steps; lane 3, purified nattokinase from Q-sepharose anion exchange column; lane 4, purified nattokinase from Sephadex G-75 column; lane 5, activity staining (zymography) clear zone showed the hydrolysis of fibrin by the purified enzyme presented in the lane 4. The arrow indicates the band of nattokinase.

\section{Table 1}

Purification stages of nattokinase from B. subtilis DB104

\begin{tabular}{lccccc}
\hline \multicolumn{1}{c}{ Steps } & $\begin{array}{c}\text { Total } \\
\text { protein } \\
(\mathbf{m g})\end{array}$ & $\begin{array}{c}\text { Specific } \\
\text { activity } \\
(\text { FU/mg) }\end{array}$ & $\begin{array}{c}\text { Total } \\
\text { activity } \\
\text { (FU) }\end{array}$ & $\begin{array}{c}\text { Purification } \\
\text { (fold) }\end{array}$ & $\begin{array}{c}\text { Yield } \\
(\%)\end{array}$ \\
\hline $\begin{array}{l}\text { Culture supernatant } \\
\text { Ammonium sulfate }\end{array}$ & 190 & 2,026 & 385.300 & 1.0 & 100 \\
$\begin{array}{l}\text { fraction } \\
\text { (40\%-70\% saturation) }\end{array}$ & 95 & 3,142 & 298,500 & 1.55 & 75.65 \\
$\begin{array}{l}\text { Q-sepharose } \\
\text { Sephadex-G75 }\end{array}$ & 34.9 & 5,457 & 190,450 & 2.69 & 49.43 \\
\hline
\end{tabular}

Source: The researcher's data analysis

Table 1 shows the salinization enzyme having an effective recovery rate compared to the original crude enzyme $75.65 \%$, the recovery efficiency was $50 \%$. The purity is 1.5 times that of the original enzyme. After chromatography of the Q-sepharose enzyme, the recovery 
activity was $49.43 \%$ and the purity was 2.7 times higher than that of the original enzyme. Compared to the Balaraman and Prabakaran study (2007), the activity-recovery efficiency was $30 \%$ when purifying tyrosinase from the broth after fermentation with Bacillus sphaericus (Balaraman \& Prabakaran, 2007).

Following gel filtration, the enzyme had a recovery activity of $41.22 \%$ and purity was 3.7 times that of the original enzyme. The result is equivalent to Wang's (2009) study of recovery efficiency of $47.6 \%$. As summarized in Table 1, the fibrinolytic enzyme was easily and quickly purified by the combination of various steps. The finally eluted proteins were subjected to SDS-PAGE, and only one band was observed in the purified sample on SDS-PAGE (Figure 3, lanes 2, 4). The molecular weight of the enzyme was approximately 27,7 kDa. With nattokinase as a standard, the final specific activity of the fibrinolytic enzyme increased more than 3.7 -fold with a $41 \%$ recovery based on the initial culture supernatant.

\subsection{In vivo thrombolysis activities}

Table 2

The mean \pm SD length of the infarcted region in the tails of the rats

\begin{tabular}{|c|c|c|}
\hline Elapsed time (h) & Groups & Infarcted region $(\mathrm{cm})$ \\
\hline \multirow{5}{*}{24} & 1 & $5.3 \pm 0.9$ \\
\hline & 2 & $2.4 \pm 0.5$ \\
\hline & 3 & 0 \\
\hline & 4 & 0 \\
\hline & 5 & $0.5 \pm 0.1$ \\
\hline \multirow{5}{*}{48} & 1 & $5.5 \pm 0.9$ \\
\hline & 2 & $1.8 \pm 0.4$ \\
\hline & 3 & $0.9 \pm 0.1$ \\
\hline & 4 & $0.9 \pm 0.1$ \\
\hline & 5 & $0.6 \pm 0.1$ \\
\hline \multirow{5}{*}{72} & 1 & $5.5 \pm 0.9$ \\
\hline & 2 & $1.0 \pm 0.2$ \\
\hline & 3 & $0.6 \pm 0.1$ \\
\hline & 4 & $0.5 \pm 0.1$ \\
\hline & 5 & $0.6 \pm 0.1$ \\
\hline
\end{tabular}

Source: The researcher's data analysis 


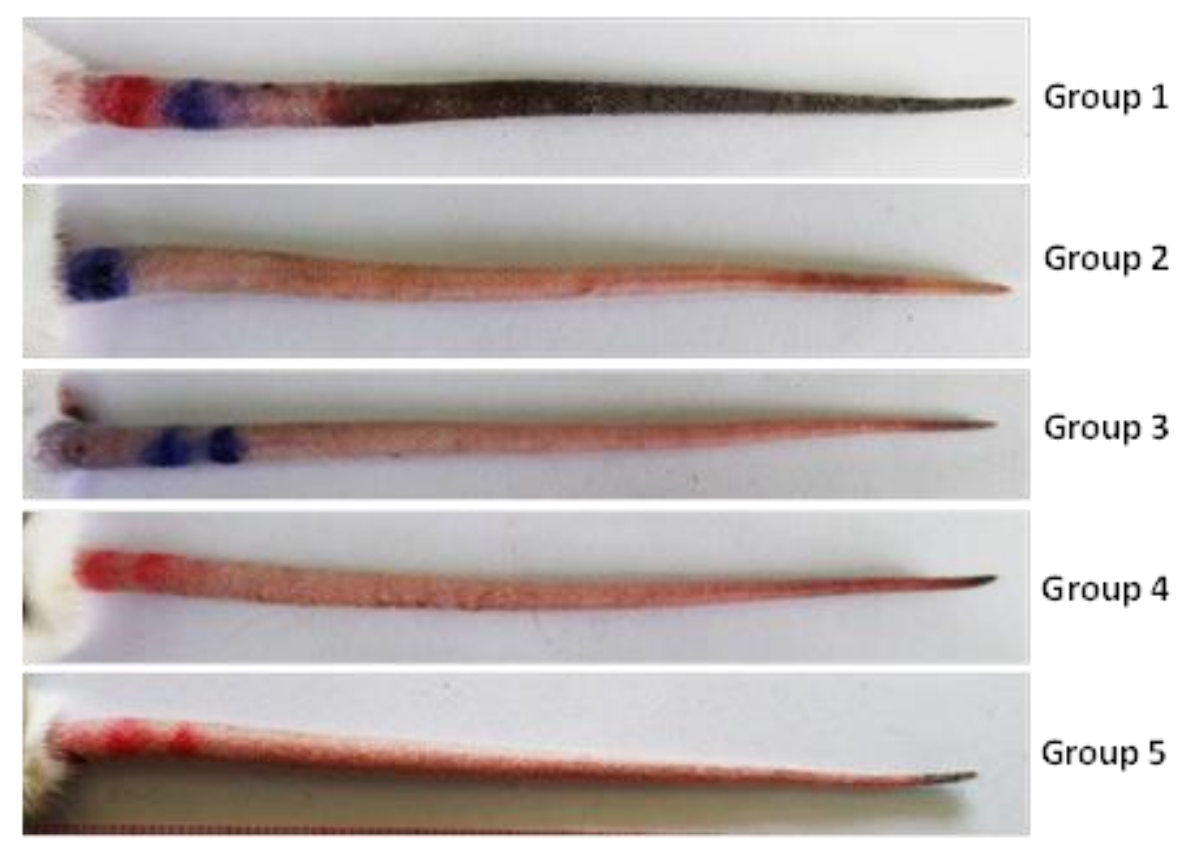

Figure 4. Photographs of the infarcted tails of rats $72 \mathrm{~h}$ after carrageenan was injected for the induction of thrombosis

To determine whether or not nattokinase exhibits thrombolytic effect in vivo, different concentrations of the enzyme were treated with graded in the k-carrageenan-induced rat tail thrombus model. After 24, 48, and $72 \mathrm{~h}$, the mean length of the infarcted regions in the tails was found to be significantly shorter for rats in the nattokinase-administered group and group 5 than for control rats (Table 2). As the administered concentration of nattokinase increased, the length of the infarcted area tended to decrease with time. The thrombus length was reduced to $82-89 \%$ tail length respectively by nattokinase administration at $72 \mathrm{~h}$, similar to the effect produced by heparin. However, Kamiya Hagimori, M., Ogasawara, M., and Arakawa (2010) reported that the frequency of thrombosis in these rats is low (approximately 5\%) (Kamiya, et al., 2010).

\section{Conclusion}

In conclusion, we observed that nattokinase which was isolated from B.subtilis DB104 by several steps included ammonium sulfate salt precipitation, then Q-sepharose and gel filtration in Sephadex G-75. The enzyme was purified 3.7-fold with a specific activity of $7,421 \mathrm{FU} / \mathrm{mg}$ of protein and $41 \%$ recovery. The purified enzyme was homogenous on SDSPAGE and its molecular weight was estimated to be $27.7 \mathrm{kDa}$. The remarkable thrombolytic activities of recombinant nattokinase were studied, and the enzyme was evaluated for its possible use as a thrombolytic agent. We also recommend additional bioavailability studies using drug delivery systems that target thrombus for developing more effective function-food products. 


\section{ACKNOWLEDGEMENTS}

The research funding from the Ho Chi Minh City Department of Science and Technology (Grant number: 116/2016/HĐ-SKHCN) was acknowledged.

\section{References}

Balaraman, K., \& Prabakaran, G. (2007). Production and purification of a fibrinolytic enzyme (thrombinase) from Bacillus sphaericus. Indian Journal of Medical Research, 126(5), 459-464.

Bradford, M. M. (1976). A rapid and sensitive method for the quantification of microgram quantities of protein utilizing the principle of protein-dye binding. Analytical Biochemistry, 72(1/2), 248-254.

Chang, C. T., Fan, M. H., Kuo, F. C., \& Sung, H. Y. (2000). Potent fibrinolytic enzyme from a mutant of Bacillus subtilis IMR-NK1. Journal of Agricultural and Food Chemistry, 48(8), 3210-3216.

Dubey, R., Kumar, J., Agrawala, D., Char, T., \& Pusp, P. (2011). Isolation, production, purification, assay and characterization of fibrinolytic enzymes (nattokinase, streptokinase and urokinase) from bacterial sources. African Journal of Biotechnology, 10(8), 1408-1420.

Fujita, M., Hong, K., Ito, Y., Fuji, R., Kariya, K., \& Nishimuro, S. (1995). Thrombolytic effect of nattokinase on a chemically induced thrombosis model in rat. Biological and Pharmaceutical Bulletin, 18(10), 1387-1391.

Fujita, M., Nomura, K., Hong, K., Ito, Y., Asada, A., \& Nishimuro, S. (1993). Purification and characterization of a strong fibrinolytic enzyme (nattokinase) in the vegetable cheese Natto, a popular soybean fermented food in Japan. Biochemical and Biophysical Research Communications, 197(3), 1340-1347.

Japan Nattokinase Association. (2000). Degradation of artificial thrombus by Nattokinase. Retrived May 18, 2012, from http://jnattokinase.org/en/jnka_nattou_1.html

Kamiya, S., Hagimori, M., Ogasawara, M., \& Arakawa, M. (2010). In vivo evaluation method of the effect of nattokinase on carrageenan-induced tail thrombosis in a rat model. Acta Haematol, 124(4), 218-224.

Kim, S. H., Choi, N. S., \& Lee, W. Y. (1998). Fibrin zymography: A direct analysis of fibrinolytic proteases on gels. Analytical Biochemistry, 263(1), 115-116. 
Kotb, E. (2012). Fibrinolytic bacterial enzyme with thrombolytic activity (Springerbriefs in microbiology). Retrived May 18, 2017, from https://www.springer.com/gp/book/9783642249792

Laemmli, U. K. (1970). Clevage of structure proteins during the assembly of the head of bacteriophage T4. Nature, 227(5259), 680-685.

Nakanishi, K., Nomura, K., Tajima, K., \& Hiratani, H. (1998). Fibrinolytic protein and production method thereof. Retrived May 19, 2017, from https://data.epo.org/publication-server/rest/v1.0/publicationdates/19910605/patents/EP0430637NWA1/document.pdf

Sumi, H., Hamada, H., Nakanishi, K., \& Hiratani, H. (1990). Enhancement of the fibrinolytic activity in plasma by oral administration of nattokinase. Acta Haemotol, 84(3), 139-143.

Sumi, H., Hamado, H., Tsushima, H., Mihara, H., \& Murica, H. (1987). A novel fibrinolytic enzyme (Nattokinase) in the vegetable cheese Natto: A typical and popular soybean food in the Japanese diet. Experientia, 43(10), 1110-1111.

Tran, T. Q., Le, A. T. T., Dinh, H. M., \& Tran, D. C. (2013). Ảnh hưởng của điều kiện nuôi cấy lên hoạt tính nattokinase từ chủng Bacillus subtilis tái tổ hợp [Effect of culture conditions on nattokinase activity from recombinant Bacillus subtilis strain]. Tạp chí Khoa hoc và Công nghệ, 51(5C), 477-482.

Urano, T., Ihara, H., \& Umemura, K. (2001). The profibrinolytic enzyme subtilisin NAT purified from Bacillus subtilis cleaves and inactivates plasminogen activator inhibitor type-I. Journal of Biological Chemistry, 276(27), 24690-24696.

Wang, C., Du, M., Zheng, D., Kong, F., Zu, G., \& Feng, Y. (2009). Purification and characterization of nattokinase from Bacillus subtilis natto B-12. Journal of Agricultural and Food Chemistry, 57(20), 9722-9729.

Whitaker, J. R. (1972). Principles of enzymology for the food science. New York, NY: Marcel Dekker INC. 